International Business Management 6(2): 176-186, 2012

ISSN: 1993-5250

(C) Medwell Journals, 2012

\title{
The Effects of Organizational Resources, Capabilities and Systems on Competitive Advantage
}

\author{
${ }^{1}$ I.I. Alimin, ${ }^{2}$ C.R. Raduan, ${ }^{3}$ U. Jegak and ${ }^{2}$ A. Haslinda \\ ${ }^{1}$ Graduate School of Management, ${ }^{2}$ Faculty of Economics and Management, \\ ${ }^{3}$ Faculty of Educational Studies, Universiti Putra Malaysia, 43400 Selangor, Malaysia
}

\begin{abstract}
Achieving a competitive advantage position relative to their competitors are the main objectives that business organizations in particular should strive to attain. This research empirically examines the importance and emphasis placed on organizational resources, capabilities and systems in their relationships with competitive advantage. This research is conducted among manufacturers listed in the Federation of Malaysian Manufacturers Directory 2008. A cross-sectional study using structured questionnaire is used to obtain responses from the manufacturers. A pilot study is initially conducted to establish the reliability of the questionnaire scales and measurements. From the subsequent actual survey, 127 respondents replied and completed the questionnaire ( $12.7 \%$ response rate). The overall findings indicate a significant positive effect of organizational resources, capabilities and systems collectively on competitive advantage, providing support and extension to the Resource-Based View (RBV). The total variance in competitive advantage accounted for by the Multiple Linear Regression (MLR) Model is $56.2 \%$. In short, the findings from this study have not only contributed to the body of knowledge or literature on the subject or issue of the relationship between organizational resources, capabilities, systems and competitive advantage but also provided vital information to both practitioners and policy makers on the subject matter.
\end{abstract}

Key words: Organizational resources, capabilities, systems and competitive advantage, Resource-Based View (RBV), pilot study, Malaysia

\section{INTRODUCTION}

Achieving a competitive advantage position relative to their competitors are the main objectives that business organizations in particular should strive to attain. In order to attain a competitive advantage level that can match those of their business rivals, business organizations have to initially understand the internal strengths and weaknesses of the organization and their potential effects on the firm's competitive advantage. By having information on the relative internal strengths and weaknesses of their organization, management can be guided in the process of making strategic business decision to improve their overall position. This research will empirically examine the importance and emphasis placed on organizational resources, capabilities and systems in their relationships with competitive advantage.

\section{Literature review}

Competitive advantage: The pursuit of competitive advantage is indeed an idea that is at the heart of much of the strategic management literature (Burden and Proctor, 2000; Fahy, 2000; Ma, 2000, 2004; Barney, 2001a, b, 2006;
Lin, 2003; Fahy et al., 2004; Cousins, 2005; Porter and Kramer, 2006; Liao and $\mathrm{Hu}, 2007$ ). Understanding sources of sustained competitive advantage has become a major area of study in strategic management (Porter, 1985, 1991; Barney, 1991; Peteraf, 1993; Ma, 1999a, b, 2004; Flint and Van Fleet, 2005; King, 2007). The resource-based view stipulates that in strategic management, the fundamental sources and drivers to firms' competitive advantage and superior performance are mainly associated with the attributes of their resources and capabilities which are valuable and costly-to-copy (Barney, 1986, 1991, 2001a; Conner, 1991; Mills et al., 2003; Peteraf and Bergen, 2003). Furthermore, other studies support the importance of having a good strategy to attain competitive advantage from the resource-based view (Hult and Ketchen, 2001; Ramsay, 2001; Foss and Knudsen, 2003; Gottschalg and Zollo, 2007). A well formulated and implemented strategy can have significant effect on the attainment of competitive advantage level (Richard, 2000; Arend, 2003; Powell, 2003; Porter and Kramer, 2006). The resourcebased view provides an avenue for organizations to plan and execute their organizational strategy by examining the position of their internal resources and capabilities

Corresponding Author: I.I. Alimin, Graduate School of Management, Universiti Putra Malaysia, 43400 Selangor, Malaysia 
towards achieving competitive advantage (Kristandl and Bontis, 2007; Sheehan and Foss, 2007). In this research, specific focus will be given to competitive advantage from the dimension of value and quality, the main elements of which consist of cost-based, product-based and servicebased. Other previous studies have shown that there is a significant relationship between cost-based advantage and the performance of organizations. Firms that enjoy cost-based competitive advantage over their rivals for example in terms of relatively lower manufacturing or production costs, lower cost of goods sold and lowerprice products have been shown to exhibit comparatively better performance (Gimenez and Ventura, 2002; Morgan et al., 2004). Furthermore, it has also been identified that there is a significant relationship between product-based advantage and performance of organizations. Firms that experience product-based competitive advantage over their rivals for example in terms of better and/or higher product quality, packaging, design and style have been shown to achieve relatively better performance (Gimenez and Ventura, 2002; Morgan et al., 2004). Similarly, research has further illustrated that there is a significant relationship between service-based advantage and performance of organizations. Firms that benefit from service-based competitive advantage compared to their rivals, for example in terms of better and/or higher product flexibility, accessibility, delivery speed, reliability, product line breadth and technical support have accomplished comparatively better performance (Gimenez and Ventura, 2002; Morgan et al., 2004).

Organizational resources: As mentioned, the ResourceBased View (RBV) of the firm predicts that certain types of resources owned and controlled by firms have the potential and promise to generate competitive advantage which eventually leads to superior firm's performance (Wernerfelt, 1984, 1995; Dierickx and Cool, 1989; Barney, 1991, 1995, 2001a, b; Peteraf, 1993; Chaharbaghi and Lynch, 1999; Fahy, 2000; Priem and Butler, 2001a, b; Miller and Ross, 2003; Morgan et al., 2004; King, 2007; Sirmon et al., 2007; Ainuddin et al., 2007). Eisenhardt and Martin (2000), Hoopes et al. (2003), Ireland et al. (2003), Mills et al. (2003) and Morgan et al. (2004) following Wernerfelt $(1984,1995)$ and Barney $(1986,1991)$ have examined and categorized resources into tangible resources i.e., human, physical organizational, financial and intangible resources i.e., reputational, regulatory, positional, functional, social and cultural.

From the categories of resources cited above, the human resources (Adner and Helfat, 2003; Datta et al., 2005; Abdullah et al., 2007; Haslinda et al., 2007;
Rose and Kumar, 2007) and the intangible resources (Oliver, 1997; Makadok, 2001) are deemed to be the more important and critical resources in attaining and sustaining competitive advantage position because of their nature being not only valuable but also hard-to-copy relative to the other types of tangible resources (i.e., physical and financial resources). In short, conceptually and empirically, resources are the foundation for attaining and sustaining competitive advantage and eventually superior firm's performance.

In this study, particular attention will be afforded to resources from the dimension of tangible and intangible, the main elements of which consist of physical, financial, experiential and human. The Resource-Based View (RBV) of the firm predicts that certain types of resources owned and controlled by firms have the potential and promise to generate competitive advantage which eventually leads to superior firm's performance. Physical resources such as the plant, machinery, equipment, production technology and capacity have contributed positively towards organizational competitive advantage and eventually result in superior firm's performance (Morgan et al., 2004; Ainuddin et al., 2007). In addition, financial resources such as the cash-in-hand, bank deposits and/or savings and financial capital (stocks and shares) have also contributed positively towards organizational competitive advantage and eventually result in superior firm's performance (Morgan et al., 2004; Ainuddin et al., 2007). Further, experiential resources such as product reputation, manufacturing experience and brand-name have contributed positively towards organizational competitive advantage and eventually result in superior firm's performance (Morgan et al., 2004; Ainuddin et al., 2007). Human resources such as the top and middle management, administrative and production employees also contribute positively towards organizational competitive advantage which eventually result in superior firm's performance (Adner and Helfat, 2003; Morgan et al., 2004; Datta et al., 2005; Ainuddin et al., 2007; Abdullah et al., 2007; Rose and Kumar, 2007).

Organizational capabilities: Studies have shown that there is a significant relationship between capabilities and competitive advantage (Prahalad and Hamel, 1990; Grant, 1996; Mascarenhas et al., 1998; Ma, 1999b; Barney, 2001a, b; Colotla et al., 2003; Wang and Lo, 2003; Morgan et al., 2004; Ray et al., 2004; King, 2007; Perez-Freije and Enkel, 2007; Sirmon et al., 2007). Following Prahalad and Hamel (1990), Stalk et al. (1992), Cockburn et al. (2000), Eisenhardt and Martin (2000), Helfat and Peteraf (2003), Hoopes et al. (2003), Mills et al. (2003), Peteraf and Bergen (2003), 
Morgan et al. (2004) and Mayer and Salomon (2006), capabilities are conceptualized and categorized as inter alia, organizational skills and collective learning, core competencies, resource development competence, organizational integration, strategic decision making and alliancing, product-development, relationship-building and informational and technological capabilities.

With excellent strategic manufacturing practices and strategic integration and deployment of resources and capabilities, competitive advantage and better performance will be attainable to firms (Schroeder et al., 2002; Ketokivi and Schroeder, 2004; Congden, 2005; McEvily and Marcus, 2005; Swink et al., 2005; Santhapparaj et al., 2006; Phusavat and Kanchana, 2007; Prajogo, 2007; Prajogo et al., 2007; Salaheldin and Eid, 2007).

In short, capabilities are a vital $\operatorname{cog}$ in the relationship between resources, competitive advantage and firm's performance because capabilities enhance the resource elements in attaining competitive advantage position and better performance. Organizational capabilities are indeed an important element in a firm's strategy (Singh et al., 2003; Ljungquist, 2007; Pryor et al., 2007) and firms' knowledge is one of the vital ingredients to attain competitive advantage and good performance (Kogut and Zander, 1992; Grandori and Kogut, 2002; Szulanski et al., 2004; Van de Ven and Johnson, 2006; Felin and Hesterly, 2007).

For this particular research, much attention will be given to capabilities from the dimension of knowledge, skill and ability, the main elements of which consist of informational, product-development and relationshipbuilding. Previous studies have illustrated that there is a significant relationship between informational capabilities and competitive advantage of organizations where informational capabilities are measured in terms of human resources training programmes, contact and job rotation among employees (Morgan et al., 2004; Ray et al., 2004).

On the other hand, research have also exhibited that there is a significant relationship between productdevelopment capabilities and competitive advantage of organizations where product-development capabilities are measured in terms of the research and development capacity, adoption of new methods in manufacturing process and product promotional and marketing activity (Morgan et al., 2004; Ray et al., 2004).

Indeed, studies have also shown that there is a significant relationship between relationship-building capabilities and competitive advantage of organizations where relationship-building capabilities are measured in terms of the networking and relationship between the firms and their suppliers, distributors and customers (Morgan et al., 2004; Ray et al., 2004; Ainuddin et al., 2007).

Organizational systems: Systems can be defined as business processes and procedures (Ray et al., 2004). According to Ray et al. (2004), business processes are actions that firms engage in to accomplish some business purpose or objective. Further, business processes can be thought of as the routines or activities that a firm develops in order to get something done (Porter, 1991). Studies have shown that systems play a significant and vital role in the ensuing resources, capabilities, competitive advantage and performance relationship (Porter and Millar, 1985; Gimenez and Ventura, 2002; Wiklund and Shepherd, 2003; Winter, 2003; Bowen and Ostroff, 2004; Ray et al., 2004; Voss, 2005; Neely, 2005; Franco-Santos et al., 2007; Perez-Freije and Enkel, 2007).

Critics of resource-based view have pinpointed that studies on resource-based view have been concentrating more on the attributes of resources and capabilities to build competitive advantage. RBV study has been paying less attention on the study of the relationship between firms' resources and capabilities and the way firms are organized. As far as organizational systems are concerned, this creates an opportunity for an empirical study. As such, it will be potentially beneficial to examine the ensuing relationship between these variables (organizational resources, capabilities and systems) and competitive advantage that has been lacking in empirical research. Studies have shown the importance of organizational strategy for attaining good performance for the firm (Thomas and Ramaswamy, 1994; Hall, 1995; Kim and Mauborgne, 2005; Rose et al., 2007, 2008; Elamin, 2008).

Excellent strategies can be implemented with good organizational systems that will bind and coordinate the organizational resources and capabilities towards attaining competitive advantage and performance for the firm. This is an area that is explored in this study as far as organizational systems are concerned.

This research pays specific attention to systems from the dimension of internal and external, the main elements of which consist of process and interactions. Process plays a significant role in harnessing organizational resources, capabilities, competitive advantage and performance relationship where process is measured in terms of the emphasis on company vision, mission, policy and procedure deployment (Gimenez and Ventura, 2002; Ray et al., 2004). Moreover, interactions also play significant and vital roles in the development of 
organizational resources, capabilities, competitive advantage and performance relationship where interactions are measured in terms of the emphasis on teamwork approach, company procurement and logistic efficiency, networking and relationship between the firms and their suppliers, distributors and customers (Gimenez and Ventura, 2002; Ray et al., 2004).

Hypotheses: This study advances the following hypotheses:

$\mathrm{H}_{1}$ : There is a significant positive relationship between organizational resources, capabilities, systems and competitive advantage

$\mathrm{H}_{1 \mathrm{a}}$ : There is a significant positive relationship between organizational resources and competitive advantage

$\mathrm{H}_{1 \mathrm{~b}}$ : There is a significant positive relationship between organizational capabilities and competitive advantage

$\mathrm{H}_{1 \mathrm{c}}$ : There is a significant positive relationship between organizational systems and competitive advantage

\section{MATERIALS AND METHODS}

This research is conducted among manufacturers listed in the Federation of Malaysian Manufacturers (2008). A cross-sectional study using structured questionnaire is used to obtain responses from the manufacturers.

Specifically, this particular research questionnaire is developed based on a modification, extension and combination of past studies on organizational resources (Morgan et al., 2004; Ainuddin et al., 2007), capabilities (Morgan et al., 2004; Ray et al., 2004; Ainuddin et al., 2007), systems (Gimenez and Ventura, 2002; Ray et al., 2004) and competitive advantage (Gimenez and Ventura, 2002; Morgan et al., 2004; Ray et al., 2004). A pilot study is initially conducted to establish the reliability of the questionnaire scales and measurements.

For this particular study, 1000 manufacturers or samples are randomly selected from the FMM Directory 2008 (the sampling frame) to be the effective unit of analysis on the basis of being convenient, offering unrestricted choice having the least bias and offering the most generalizability (Sekaran, 2005).

As for the simple random sampling procedure or method, its choice is justified since such a sampling method has been adopted and applied previously in other earlier empirical studies concerning manufacturers in particular (Morgan et al., 2004; Jusoh et al., 2008; Jusoh and Parnell, 2008).

In short, given the financial and time constraints faced by the researcher in conducting this study, the choice of the sampling frame and the simple random sampling procedure can be justified. From the subsequent actual survey, 127 respondents replied and completed the questionnaire ( $12.7 \%$ response rate).

\section{RESULTS}

A standard Multiple Linear Regression (MLR) is used to assess the ability of three variables (resources, capabilities and systems) to predict levels of competitive advantage. Preliminary analyses are conducted to ensure there is no violation of the assumptions of normality, linearity, multicollinearity and homoscedasticity. The model is able to explain $56.2 \%$ (Table 1 ) of the variance in perceived competitive advantage, $\mathrm{F}(3,123)=52.61$, $\mathrm{p}<0.001$ (Table 2). As shown in Table 3, only two variables (systems and capabilities) are statistically significant with systems recording a higher beta value $(\beta=0.40, \mathrm{p}<0.001)$ than capabilities $(\beta=0.30, \mathrm{p}<0.05)$. Table 1-4 and Fig. 1-3 show the detail results of the multiple linear regression analysis.

Table 3 shows that from collinearity statistics there is no problem of multicollinearity among the predictor variables as the tolerance values are all above the minimum 0.10 level and the VIF statistics are all below the 10.0 critical level (Pallant, 2007). As for the outliers among the predictor variables, Table 4 shows that the Mahalanobis distance maximum value of 10.69 is below the critical value of 16.27 at an alpha level of 0.001 as per the guidelines recommended by Tabachnick and Fidell (2007) for detecting critical value for outliers (i.e., critical value of 16.27 for three independent variables). This means that there is no problem of outliers among the independent variables that might affect the result of the regression analysis.

Figure 1 (histogram) shows that the regression standardized residual for competitive advantage is normally distributed (a bell-shaped distribution line or curve).

Figure 2 (normal P-P plot of regression standardized residual for competitive advantage) further illustrates that all the points lie in a reasonably straight diagonal line from bottom left to top right. This suggests that there are no major deviations from normality. Figure 3 (Scatterplot of the standardized residuals) also suggests that the residuals are roughly rectangularly distributed with most of the scores concentrated in the centre (along the zero point).

As such from the above results, they indicate that there are no problems or violation of the assumptions of multicollinearity, normality, linearity, homoscedasticity and equality of variance. Hence, it is reasonable to state 
Int. Business Manage., 6 (2): 176-186, 2012

Table 1: Model summary ${ }^{b}$

\begin{tabular}{|c|c|c|c|c|c|c|c|c|c|}
\hline \multirow[b]{2}{*}{ Model } & \multirow[b]{2}{*}{$\mathrm{R}$} & \multirow[b]{2}{*}{$\mathrm{R}^{2}$} & \multirow[b]{2}{*}{ Adjusted $\mathrm{R}^{2}$} & \multirow[b]{2}{*}{ SE of the estimate } & \multicolumn{5}{|c|}{ Change statistics } \\
\hline & & & & & $\mathrm{R}^{2}$ change & F change & $\mathrm{df}_{1}$ & $\mathrm{df}_{2}$ & Sig. F change \\
\hline$\underline{1}$ & $0.750^{\mathrm{a}}$ & 0.562 & 0.551 & 0.30526 & 0.562 & 52.607 & 3 & 123 & 0.000 \\
\hline \multicolumn{10}{|c|}{ Table 2: ANOVA } \\
\hline \multicolumn{2}{|l|}{ Models } & \multicolumn{2}{|c|}{ Sum of square } & $\mathrm{df}$ & \multicolumn{2}{|c|}{ Mean of square } & \multicolumn{2}{|c|}{ F-value } & Sig. \\
\hline \multicolumn{2}{|c|}{ Regression } & \multicolumn{2}{|c|}{14.706} & 3 & \multicolumn{2}{|c|}{4.902} & \multicolumn{2}{|c|}{52.607} & $0.000^{\mathrm{a}}$ \\
\hline \multicolumn{2}{|c|}{ Residual } & \multicolumn{2}{|c|}{11.461} & 123 & \multicolumn{2}{|c|}{0.093} & \multicolumn{2}{|l|}{-} & - \\
\hline \multicolumn{2}{|l|}{ Total } & & & 126 & \multicolumn{2}{|c|}{ - } & \multicolumn{2}{|l|}{ - } & - \\
\hline
\end{tabular}

${ }^{\mathrm{a}}$ Predictors: (Constant), sy stems, resources, capabilities; ${ }^{b}$ Dependent variable: Competitive advantage

Table 3: Coefficients

\begin{tabular}{lccccccccc}
\hline & Unstandardized coefficients & \multicolumn{2}{c}{$\begin{array}{c}\text { Standardized } \\
\text { coefficients }\end{array}$} & & & $95 \%$ confidence interval for B & Collinearity statistics \\
Models & $-\mathrm{B}$ & $\mathrm{SE}$ & $(\beta)$ & t-value & Sig. & Lower bound & Upper bound & Tolerance & VIF \\
\hline Constant & 1.414 & 0.219 & - & 6.443 & 0.000 & 0.980 & 1.848 & - & - \\
Resource & 0.114 & 0.093 & 0.115 & 1.235 & 0.219 & -0.069 & 0.298 & 0.409 & 2.446 \\
Capabilities & 0.243 & 0.087 & 0.295 & 2.782 & 0.006 & 0.070 & 0.416 & 0.317 & 3.150 \\
Systems & 0.274 & 0.071 & 0.399 & 3.864 & 0.000 & 0.134 & 0.415 & 0.333 & 3.001 \\
\hline
\end{tabular}

${ }^{a}$ Dependent variable: Competitive advantage

Table 4: Residuals statistics ${ }^{\mathrm{a}}$

\begin{tabular}{lcccc}
\hline Parameters & Minimum & Maximum & Mean \pm SD & $\mathrm{N}$ \\
\hline Predicted value & 2.830800 & 4.57140 & $3.73020 \pm 0.34164$ & 127 \\
Std. predicted value & -2.633000 & 2.46200 & $0.00000 \pm 1.00000$ & 127 \\
Standard error of & 0.02700 & 0.09300 & $0.05200 \pm 0.01600$ & 127 \\
predicted value & & & & \\
Adjusted predicted value & 2.79310 & 4.62520 & $3.72960 \pm 0.34398$ & 127 \\
Residual & -0.81915 & 0.66997 & $0.00000 \pm 0.30160$ & 127 \\
Std. residual & -2.68300 & 2.19500 & $0.00000 \pm 0.98800$ & 127 \\
Stud. residual & -2.77300 & 2.23000 & $0.00100 \pm 1.00500$ & 127 \\
Deleted residual & -0.87447 & 0.69181 & $0.00054 \pm 0.31213$ & 127 \\
Stud. deleted residual & -2.85200 & 2.26700 & $0.00100 \pm 1.01300$ & 127 \\
Mahal. distance & 0.00500 & 10.68700 & $2.97600 \pm 2.47200$ & 127 \\
Cook's distance & 0.00000 & 0.13000 & $0.00900 \pm 0.01700$ & 127 \\
Centered leverage value & 0.00000 & 0.08500 & $0.02400 \pm 0.02000$ & 127 \\
\hline
\end{tabular}

${ }^{\mathrm{a}}$ Dependent variable: Competitive advantage

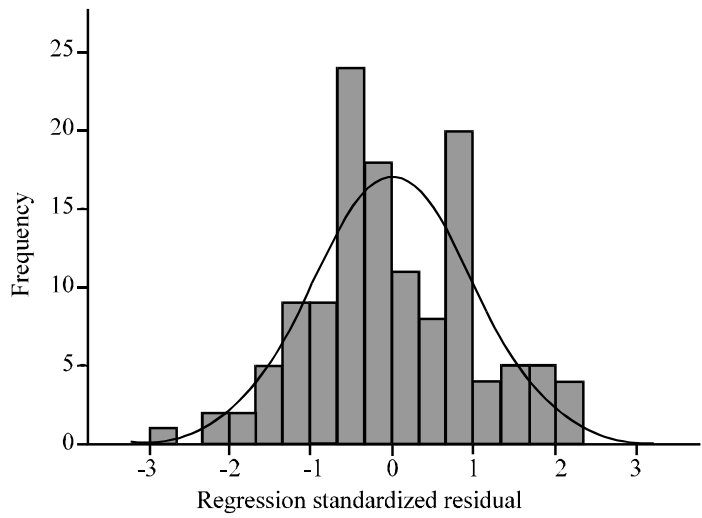

Fig. 1: Histogram (Dependent variable: Compwetitive advantage)

that the standard multiple regression model above is stable and good to explain the variance in competitive advantage. The model implies that there is a significant positive relationship between organizational resources, capabilities, systems and competitive advantage. The

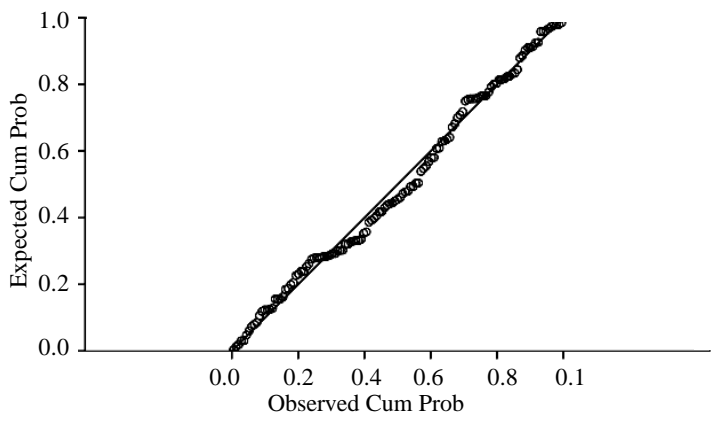

Fig. 2: Normal P-P plot of regression standardized residual (Dependent variable: Competitive advantage)

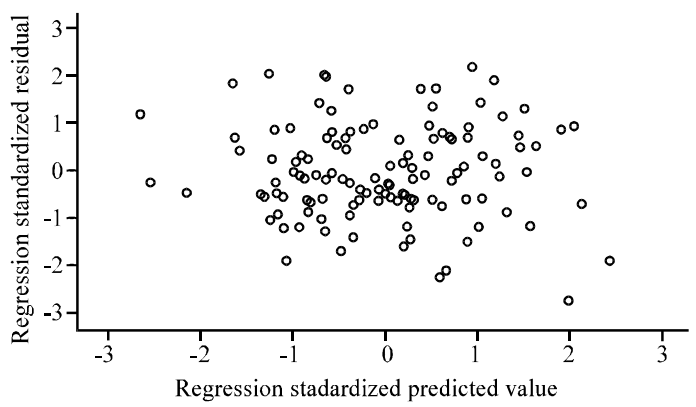

Fig. 3: Scatter plot (Dependent variable: Compwetitive advantage)

total variance in competitive advantage explained by the model as a whole is $56.2 \%$ (Table 1$), \mathrm{F}(3,123)=52.61$, $\mathrm{p}<0.001$ (Table 2). These findings support hypothesis 1 . As for the individual dimension as shown in Table 3, only two independent variables (systems and capabilities) are statistically significant with systems recording a higher beta value $(\beta=0.40, p<0.001)$ than capabilities $(\beta=0.30$, 
$\mathrm{p}<0.05)$. This means only hypothesis $1_{b}$ that there is a significant positive relationship between organizational capabilities and competitive advantage and hypothesis $1_{c}$ that there is a significant positive relationship between organizational systems and competitive advantage are fully supported. The individual dimension result does not provide full support for hypothesis $1_{\mathrm{a}}$ which means there is no significant relationship between organizational resources and competitive advantage. Nonetheless, the beta value or direction of the regression coefficient is positive $(\beta=0.12, \mathrm{p}>0.05)$ suggesting a partial support. As such in mathematical terms, the MLR Model equation can be shown as follows:

Where:

$$
\mathrm{Y}(\mathrm{CA})=\mathrm{a}+\mathrm{b}_{1} \mathrm{X}_{1}+\mathrm{b}_{2} \mathrm{X}_{2}+\mathrm{b}_{3} \mathrm{X}_{3}+\mathrm{e}
$$

$\mathrm{Y}=$ Competitive Advantage (CA)

$\mathrm{X}_{1}=$ Organizational resources

$\mathrm{X}_{2}=$ Organizational capabilities

$\mathrm{X}_{3}=$ Organizational systems

$\mathrm{a}=$ Constant

$\mathrm{e}=$ Error terms

Based on the MLR result (Table 3), the estimated MLR equation is as:

$$
\mathrm{CA}=1.414+0.243\left(\mathrm{X}_{\mathbf{z}}\right)+0.274(\mathrm{X})+\mathrm{e}
$$

The MLR equation implies that one standard deviation increase in capabilities $\left(\mathrm{X}_{2}\right)$, holding systems $\left(\mathrm{X}_{3}\right)$ constant will result in 0.243 standard deviation increase in competitive advantage. Also, one standard deviation increase in systems $\left(\mathrm{X}_{3}\right)$, holding capabilities $\left(\mathrm{X}_{2}\right)$ constant will result in 0.274 standard deviation increase in competitive advantage. The result for the regression coefficient for resources $\left(\mathrm{X}_{1}\right)$ is not statistically significant $(\beta=0.12, \mathrm{p}>0.05)$.

\section{DISCUSSION}

The findings from this study are parallel to those of Santhapparaj et al. (2006) which analyze the competitive factors of semiconductor manufacturers in Malaysia. Data are collected and analyzed from self-administered questionnaires distributed to a total of 200 managers from ten different companies operating within two Free Trade Zones (FTZ) located in Ulu Klang and Sungei Way, Malaysia, respectively. Their study observes that there is a significant relationship between organizational resources, capabilities, systems and competitive advantage. Organizational resources (human capital development and manufacturing flexibility), capabilities (product quality improvement and technical skill development) and systems (integrated network and efficient daily operations) are identified as critical factors towards achieving competitive advantage.

In another study by Phusavat and Kanchana (2007) on the issue of competitive priorities of manufacturing firms in Thailand, it is discovered that there is a significant relationship between organizational resources, capabilities, systems and competitive advantage. Ten manufacturers respond to a survey which finds that resources (product quality and flexibility), capabilities (know-how and innovativeness) and systems (customer service and delivery) are the major priorities to attain competitive advantage. The result of the study is also in tandem with that of Morgan et al. (2004). They discover that the available resources $(\beta=0.26$, t-value $=2.69$, $\mathrm{p}<0.05)$ and capabilities $(\beta=0.56$, t-value $=4.63, \mathrm{p}<0.05)$ are significantly and positively related to competitive advantage. As far as the independent variable's individual dimension is concerned, only two independent variables (organizational systems and capabilities) are found to be statistically significant in the study. The results indicate that systems register a higher beta value $(\beta=0.40, p<0.001)$ compared to capabilities $(\beta=0.30$, $\mathrm{p}<0.05$ ). This result supports the finding of the study by Morgan et al. (2004) as far as the significant positive relationship between capabilities and competitive advantage is concerned.

However, the individual dimension's result of the study does not provide full support for the study by Morgan et al. (2004) which means there is no significant relationship between organizational resources and competitive advantage. Nonetheless, the beta value or direction of the regression coefficient registers a positive value $(\beta=0.12, \mathrm{p}>0.05)$. This result suggests partial support for the study by Morgan et al. (2004) where they discover that the available resources are significantly and positively related to competitive advantage $(\beta=0.26$, t-value $=2.69, \mathrm{p}<0.05$ )

A reasonable explanation that can be given for this inconsistent finding is that when these three independent variables (resources, capabilities and systems) are pooled together, their separate individual effects are somewhat obscured relative to the aggregate effects. The resources' individual statistical significance relative strength seems to be reduced when it is examined together with the other two variables (capabilities and systems). This is understandable because although all the independent variables register positive beta values, the relative strength of their coefficients vary from one variable to another. The results indicate that systems register a higher beta value $(\beta=0.40, \mathrm{p}<0.001)$ compared to 
capabilities $(\beta=0.30, p<0.05)$ and resources $(\beta=0.12$, $\mathrm{p}>0.05$ ) in their relationship with competitive advantage. This implies that when the independent variables (resources, capabilities and systems) are pooled together in the MLR Model, they generate significant overlapping effects collectively. However when examined individually, possibly there is a lot of shared variance that is statistically removed and thus reducing the variable's individual statistical significance. Overall, the result of this study provides empirical support for other previous studies (Barney, 2001a, b, 2007; Priem and Butler, 2001a, b; King, 2007; Sirmon et al., 2007) on the notion of the significant positive relationship between organizational resources, capabilities, systems and competitive advantage.

\section{CONCLUSION}

The overall findings indicate a significant positive effect of organizational resources, capabilities and systems collectively on competitive advantage, providing support and extension to the Resource-Based View (RBV). The total variance in competitive advantage accounted for by the MLR Model is $56.2 \%$. As such the overall contribution of this research to the literature is that it has managed to further extend and strengthen the theoretical discourse on the RBV of competitive advantage in particular by empirically illustrating the extent or magnitude of the relationship between the organizational resources, capabilities, systems and competitive advantage as perceived by Malaysian manufacturers. In other words, this study shows the relative effects of organizational resources, capabilities and systems on competitive advantage.

From the practical aspect, the findings from this research have contributed to the management of organizations in terms of providing valuable input and awareness on the factors or variables to consider as far as attaining competitive advantage is concerned. The research illustrates with empirical evidence that it is vital for organizations to have sound work systems to organize both their internal capabilities and resources towards achieving competitive advantage. In other words, to attain competitive advantage firms need to improve their R\&D and product promotion capabilities and also enhance their work systems in terms of the manufacturing process and Standard Operating Procedures (SOP). In addition, organizations need to further enhance their aggregate resources, especially physical and human resources as well as to encourage healthy teamwork among their employees and adopt Key Performance Indicators (KPI) in their operation and also strengthen their networking or interactions with their suppliers and distributors. In terms of the firm's policy, the findings from this study could help policy makers in making decisions concerning the firm's internal attributes that should be given more attention or priority relative to the others. For example, the firm needs to enhance their work systems, manufacturing or production systems and HRM policies relative to their organizational financial policy in order to improve their overall organizational competitive advantage and performance. Further, firms also need to strengthen their R\&D policy and public relation exercise to attain a better competitive advantage position compared to their business rivals.

\section{IMPLICATIONS}

The theoretical implication of this study is that it supports and extends the RBV of competitive advantage by illustrating the need for systematic management of resources and capabilities towards attaining competitive advantage. While supporting the significance of the organizing factor in the VRIO (Value, Rareness, Inimitability and Organization) framework of the RBV of competitive advantage.

The research illustrates that by examining these variables (resources, capabilities and systems) in aggregate, their individual statistical significance might diminish in their relationships with competitive advantage (resources was found to be statistically non-significant). However, the implications of these findings do not mean that the organizational resources are not important factors and/or elements towards attaining competitive advantage.

It specifically reflects the perceived priorities of the Malaysian manufacturers as far as the importance and ranking of these particular variables (resources, capabilities and systems) individually towards achieving competitive advantage is concerned. In other words, it illustrates the magnitude of importance placed upon the organizational resources, capabilities and systems in their relationship with competitive advantage.

In short, the findings from this study have not only contributed to the body of knowledge or literature on the subject or issue of the relationship between organizational resources, capabilities, systems and competitive advantage but also provided vital information to both practitioners and policy makers on the subject matter. Nonetheless, other future research might want to consider examining the relationship between other potential exogenous variables (for example organizational structure and/or strategy) and their probable effects on the firm's competitive advantage and performance. Furthermore, 
adopting a longitudinal study and/or a qualitative research approach using other potential sampling frame (for example the service sector industry directory) to address and examine competitive advantage might be another future empirical research direction to be considered.

This course of action will have a potential not only to further extend and expand the literature on competitive advantage from the RBV but also to generate more input towards the practical aspect of the strategic management of organizations.

\section{REFERENCES}

Abdullah, H., R.C. Rose and N. Kumar, 2007. Human resource development strategies: The Malaysian scenario. J. Soc. Sci., 3: 213-222.

Adner, R. and C.E. Helfat, 2003. Corporate effects and dynamic managerial capabilities. Strategic Manage. J., 24: 1011-1025.

Ainuddin, R.A., P.W. Beamish, J.S. Hulland and M.J. Rouse, 2007. Resource attributes and firm performance in international joint ventures. J. World Bus., 42: 47-60.

Arend, R.J., 2003. Revisiting the logical and research considerations of competitive advantage. Strategic Manage. J., 24: 279-284.

Barney, J.B., 1986. Strategic factor markets: Expectations, luck and business strategy. Manage. Sci., 32: 1231-1241.

Barney, J., 1991. Firm resources and sustained competitive advantage. J. Manage., 17: 99-120.

Barney, J.B., 1995. Looking inside for competitive advantage. Acad. Manage. Exec., 9: 49-61.

Barney, J.B., 2001 a. Is the resource-based view a useful perspective for strategic management research? Yes. Acad. Manage. Rev., 26: 41-56.

Barney, J.B., 2001b. Resource-based theories of competitive advantage: A ten-year retrospective on the resource-based view. J. Manage., 27: 643-651.

Barney, J.B., 2006. Gaining and Sustaining Competitive Advantage. 3rd Edn., Prentice Hall, New Jersey, ISBN: 978-0131470941, Pages: 592.

Bowen, D.E. and C. Ostroff, 2004. Understanding HRMFirm performance linkages: The role of the strength of the HRM system. Acad. Manage. Rev., 29: 203-221.

Burden, R. and T. Proctor, 2000. Creating a sustainable competitive advantage through training. Team Performance Manage., 6: 90-97.

Chaharbaghi, K. and R. Lynch, 1999. Sustainable competitive advantage: Towards a dynamic resourcebased strategy. Manage. Decision, 37: 45-50.
Cockburn, I.M., R.M. Henderson and S. Stern, 2000. Untangling the origins of competitive advantage. Strategic Manage. J., 21: 1123-1145.

Colotla, I., Y. Shi and M.J. Gregory, 2003. Operation and Performance of international manufacturing networks. Int. J. Operat. Prod. Manage., 23: 1184-1206.

Congden, S.W., 2005. Firm performance and the strategic fit of manufacturing technology. Compet. Rev., 15: 14-32.

Conner, K.R., 1991. A historical comparison of resourcebased theory and five schools of thought within industrial organization economics: Do we have a new theory of the firm?. J. Manage., 17: 121-154.

Cousins, P.D., 2005. The alignment of appropriate firm and supply strategies for competitive advantage. Int. J. Operat. Prod. Manage., 25: 403-428.

Datta, D.K., J.P. Guthrie and P.M. Wright, 2005. Human resource management and labour productivity: Does industry matter?. Acad. Manage. J., 48: 135-145.

Dierickx, I. and K. Cool, 1989. Asset stock accumulation and sustainability of competitive advantage. Manage. Sci., 35: 1504-1511.

Eisenhardt, K.M. and J.A. Martin, 2000. Dynamic capabilities: What are they?. Strategic Manage. J., 21: 1105-1121.

Elamin, A.M., 2008. Methods of researching strategy process in developing countries. Eur. J. Econ. Finance Administrative Sci., 10: 200-212.

Fahy, J., 2000. The resource-based view of the firm: Some stumbling-blocks on the road to understanding sustainable competitive advantage. J. Eur. Ind. Train., 24: 94-104.

Fahy, J., F. Farrelly and P. Quester, 2004. Competitive advantage through sponsorship: A conceptual model and research propositions. Eur. J. Market., 38: 1013-1030.

Federation of Malaysian Manufacturers, 2008. Malaysian Industries: FMM Directory 2008. 39th Edn., Federation of Malaysian Manufacturers, Kuala Lumpur.

Felin, T. and W.S. Hesterly, 2007. The knowledge-based view, nested heterogeneity and new value creation: Philosophical considerations on the locus of knowledge. Acad. Manage. Rev., 32: 195-218.

Flint, G.D. and D.D. Van Fleet, 2005. A comparison and contrast of strategic management and classical economic concepts: Definitions, comparisons and pursuit of advantages. Journal of Business Inquiry, Utah Valley State College, USA.

Foss, N.J. and T. Knudsen, 2003. The resource-based tangle: Towards a sustainable explanation of competitive advantage. Manage. Decis. Econ., 24: 291-307. 
Franco-Santos, M., M. Kennerley, P. Micheli, V. Martinez and S. Mason et al., 2007. Towards a definition of a business performance measurement system. Int. J. Operat. Prod. Manage., 27: 784-801.

Gimenez, C. and A. Ventura, 2002. Supply chain management as a competitive advantage in the Spanish grocery sector. Published Working Paper. No. 2, 04/2002, Universitat Pompeu Fabra (UPF), Barcelona, Spain.

Gottschalg, O. and M. Zollo, 2007. Interest alignment and competitive advantage. Acad. Manage. Rev., 32: 418-437.

Grandori, A. and B. Kogut, 2002. Dialogue on organization and knowledge. Organiz. Sci., 13: 224-231.

Grant, R.M., 1996. Toward a knowledge-based theory of the firm. Strategic Mgmt. J., 17: 109-122.

Hall, E.H., 1995. Corporate diversification and performance: An investigation of causality. Aust. J. Manage., 20: 25-42.

Haslinda, A., C.R. Raduan and K. Naresh, 2007. Human resource development practices in Malaysia: A case of manufacturing industries. Eur. J. Soc. Sci., 5: 37-52.

Helfat, C.E. and M.A. Peteraf, 2003. The dynamic resource-based view: Capability lifecycles. Strategic Manage. J., 24: 997-1010.

Hoopes, D.G., T.L. Madsen and G. Walker, 2003. Why is there a Resource-based View? Toward a theory of competitive heterogeneity. Strategic Manage. J., 24: 889-902.

Hult, G.T.M. and D.J. Ketchen, 2001. Does market orientation matter?: A test of the relationship between positional advantage and performance. Strategic Manage. J., 22: 899-906.

Ireland, R.D., M.A. Hitt and D.G. Sirmon, 2003. A model of strategic entrepreneurship: the construct and its dimensions. J. Manage., 29: 963-989.

Jusoh, R. and J.A. Parnell, 2008. Competitive strategy and performance measurement in the Malaysian context: An exploratory study. Manage. Decis., 46: 5-31.

Jusoh, R., D.N. Ibrahim and Y. Zainuddin, 2008. The performance consequence of multiple performance measures usage: Evidence from the Malaysian manufacturers. Int. J. Prod. Perform. Manage., 57: 119-136.

Ketokivi, M. and R. Schroeder, 2004. Manufacturing practices, strategic fit and performance: A routinebased view. Int. J. Operat. Prod. Manage., 24: 171-191.

Kim, W.C. and R. Mauborgne, 2005. Blue Ocean strategy: From theory to practice. California Manage. Rev., 47: 105-121.

King, A.W., 2007. Disentangling interfirm and intrafirm causal ambiguity: A conceptual model of causal ambiguity and sustainable competitive advantage. Acad. Manage. Rev., 32: 156-178.
Kogut, B. and U. Zander, 1992. Knowledge of the firm, combinative capabilities and the replication of technology. Organization Sci., 3: 383-397.

Kristandl, G. and N. Bontis, 2007. Constructing a definition for intangibles using the resource based view of the firm. Manage. Decis., 45: 1510-1524.

Liao, S.H. and T.C. Hu, 2007. Knowledge transfer and competitive advantage on environmental uncertainty: An empirical study of the Taiwan semiconductor industry. Technovation, 27: 402-411.

Lin, B.W., 2003. Technology transfer as technological learning: A source of competitive advantage for firms with limited $\mathrm{R}$ and $\mathrm{D}$ resources. R.D Manage., 33: $327-341$.

Ljungquist, U., 2007. Core competency beyond identification: Presentation of a model. Manage. Decis., 45: 393-402.

Ma, H., 1999a. Anatomy of competitive advantage: A select framework. Manage. Decis., 37: 709-718.

Ma, H., 1999b. Creation and preemption for competitive advantage. Manage. Decis., 37: 259-267.

$\mathrm{Ma}, \mathrm{H} ., 2000$. Competitive advantage and firm performance. Compet. Rev., 10: 16-16.

Ma, H., 2004. Toward global competitive advantage: Creation, competition, cooperation and co-option. Manage. Decis., 42: 907-924.

Makadok, R., 2001. Toward a synthesis of the resourcebased and dynamic-capability views of rent creation. Strategic Manage. J., 22: 387-401.

Mascarenhas, B., A. Baveja and M. Jamil, 1998. Dynamics of core competencies in leading multinational companies. California Manage. Rev., 40: 117-132.

Mayer, K.J. and R.M. Salomon, 2006. Capabilities, contractual hazards and governance: Integrating resource-based and transaction cost perspectives. Acad. Manage. J., 49: 942-959.

McEvily, B. and A. Marcus, 2005. Embedded ties and the acquisition of competitive capabilities. Strategic Manage. J., 26: 1033-1055.

Miller, S.R. and A.D. Ross, 2003. An exploratory analysis of resource utilization across organizational units: Understanding the resource-based view. Int. J. Operat. Prod. Manage., 23: 1062-1083.

Mills, J., K. Platts and M. Bourne, 2003. Competence and resource architectures. Int. J. Operat. Prod. Manage., 23: 977-994.

Morgan, N.A., A. Kaleka and C.S. Katsikeas, 2004. Antecedents of export venture performance: A theoretical model and empirical assessment. J. Market., 68: 90-108.

Neely, A., 2005. The evolution of performance measurement research: Developments in the last decade and a research agenda for the next. Int. J. Operat. Prod. Manage., 25: 1264-1277. 
Oliver, C., 1997. Sustainable competitive advantage: Combining institutional and resource-based views. Strategic Manage. J., 18: 697-713.

Pallant, J., 2007. SPSS Survival Manual-A Step by Step Guide to Data Analysis Using SPSS for Windows (Version 15). 3rd Edn., Open University Press, UK., ISBN: 978-0335223664, Pages: 352.

Perez-Freije, J. and E. Enkel, 2007. Creative tension in the innovation process: How to support the right capabilities. Eur. Manage. J., 25: 11-24.

Peteraf, M.A. and M.E. Bergen, 2003. Scanning dynamic competitive landscapes: A market-based and resource-based framework. Strategic Manage. J., 24: 1027-1041.

Peteraf, M.A., 1993. The cornerstones of competitive advantage: A resource-based view. Strategic Manage. J., 14: 179-191.

Phusavat, K. and R. Kanchana, 2007. Competitive priorities of manufacturing firms in Thailand. Ind. Manage. Data Syst., 107: 979-996.

Porter, M.E. and M.R. Kramer, 2006. Strategy and society: The link between competitive advantage and corporate social responsibility. Harvard Bus. Rev., 84: 78-93.

Porter, M.E. and V.E. Millar, 1985. How information gives you competitive advantage. Harvard Bus. Rev., 63: 149-160.

Porter, M.E., 1985. Competitive Advantage. 1st Edn., Free Press, New York.

Porter, M.E., 1991. Towards a dynamic theory of strategy. Strategic Manage. J., 12: 95-117.

Powell, T.C., 2003. Strategy without ontology. Strategic Manage. J., 24: 285-291.

Prahalad, C.K. and G. Hamel, 1990. The core competence of the corporation. Harvard Bus. Rev., 90: 79-91.

Prajogo, D.I., 2007. The relationship between competitive strategies and product quality. Ind. Manage. Data Syst., 107: 69-83.

Prajogo, D.I., T. Laosirihongthong, A.S. Sohal and S. Boon-Itt, 2007. Manufacturing strategies and innovation performance in newly industrial countries. Ind. Manage. Data Syst., 107: 52-68.

Priem, R.L. and J.E. Butler, 2001a. Is the resource-based view a useful perspective for strategic management research?. Acad. Manage. Rev., 26: 22-40.

Priem, R.L. and J.E. Butler, 2001b. Tautology in the resource-based view and the implications of externally determined resource value: Further comment. Acad. Manage. Rev., 26: 57-66.

Pryor, M.G., D. Anderson, L.A. Toombs and J.H. Humphreys, 2007. Strategic implementation as a core competency: The 5P's model. J. Manage. Res., 7: 3-17.
Ramsay, J., 2001. The resource based perspective, rents and purchasing's contribution to sustainable competitive advantage. J Supply Chain Manage. Summer, 2001: 38-47.

Ray, G., J.B. Barney and W.A. Muhanna, 2004. Capabilities, business processes, and competitive advantage: Choosing the dependent variable in empirical tests of the resource-based view. Strategic Manage. J., 25: 23-37.

Richard, O.C., 2000. Racial Diversity, business strategy and firm performance: A resource-based view. Acad. Manage. J., 43: 164-177.

Rose, R.C. and N. Kumar, 2007. Blockade for career advancement in japanese organization abroad: The case of malaysian subsidiaries. Am. J. Applied Sci., 4: 8-13.

Rose, R.C., N. Kumar and H.I. Tbrahim, 2007. The effect of manufacturing strategy on organizational performance. Eur. J. Econ. Finance Admin. Sci., 9: $38-47$.

Rose, R.C., N. Kumar and H.I. Ibrahim, 2008. Relationship between strategic human resource management and organizational performance: Evidence from selected Malaysian firms. Eur. J. Econ., Finance Admin. Sci., 10: 86-97.

Salaheldin, S.I. and R. Eid, 2007. implementation of world class manufacturing techniques in Egyptian manufacturing firms. Ind. Manage. Data Syst., 107: $551-566$.

Santhapparaj, A.S., J. Sreenivasan and J.C.K. Loong, 2006. Competitive factors of semiconductor industry in Malaysia: The managersâ_ ${ }^{\text {TM }}$ perspectives. Competitiveness Rev. Int. Bus. J. Incorporating J. Global Competitiveness, 16: 197-211.

Schroeder, R.G., K.A. Bates and M.A. Junttila, 2002. A resource-based view of manufacturing strategy and the relationship to manufacturing performance. Strategic Manage. J., 23: 105-117.

Sekaran, U., 2005. Research Methods for Business: A Skill-Building Approach. 4th Edn., John Wiley and Sons, Inc., New York, USA.

Sheehan, N.T. and N.J. Foss, 2007. Enhancing the prescriptiveness of the resource-based view through Porterian activity analysis. Manage. Decis., 45: 450-461.

Singh, K., S.H. Ang and S.M. Leong, 2003. Increasing replication for knowledge accumulation in strategy research. J. Manage., 29: 533-549.

Sirmon, D.G., M.A. Hitt and R.D. Ireland, 2007. Managing firm resources in dynamic environments to create value: Looking inside the black box. Acad. Manage. Rev., 32: 273-292. 
Stalk, G., P. Evans and L.E. Shulman, 1992. Competing on capabilities: The new rules of corporate strategy. Harvard Bus. Rev., 70: 57-69.

Swink, M., R. Narasimhan and S.W. Kim, 2005. Manufacturing practices and strategy integration: Effects on cost efficiency, flexibility and marketbased performance. Decis. Sci., 36: 427-427.

Szulanski, G., R. Cappetta and R.J. Jensen, 2004. When and how trustworthiness matters: Knowledge transfer and the moderating effect of causal ambiguity. Organiz. Sci., 15: 600-613.

Tabachnick, B.G. and L.S. Fidell, 2007. Using Multivariate Statistics. 5th Edn., Pearson Education, Boston, Massachusetts.

Thomas, A.S. and K. Ramaswamy, 1994. Matching managers to strategy: An investigation of performance implications and boundary conditions. Aust. J. Manage., 19: 73-93.
Van de Ven, A.H. and P.E. Johnson, 2006. Knowledge for theory and practice. Acad. Manage. Rev., 31: 802-821.

Voss, C.A., 2005. Alternative paradigms for manufacturing strategy. Int. J. Operat. Prod. Manage., 25: 1211-1222.

Wang, Y. and H. Lo, 2003. Customer-focused performance and the dynamic model for competence building and leveraging: A resource-based view. J. Manage. Dev., 22: 483-526.

Wernerfelt, B., 1984. A Resource-based view of the firm. Strategic Manage. J., 5: 171-180.

Wernerfelt, B., 1995. The resource-based view of the firm: Ten years after. Strategic Manage. J., 16: 171-174.

Wiklund, J. and D. Shepherd, 2003. Knowledge-based resources, entrepreneurial orientation and the performance of small and medium-sized business. Strategic Manage. J., 24: 1307-1314.

Winter, S., 2003. Understanding dynamic capabilities. Strategic Manage. J., 24: 991-995. 